\title{
An Evaluation of Quality of Working Life in the Tomsk Region
}

\author{
Evgeniya Ufimtseva ${ }^{1},{ }^{*}$ Irina Volchkova ${ }^{2}$, Nikolay Shadeiko ${ }^{2}$, Olga Gevorgyan ${ }^{2}$ \\ ${ }^{1}$ Tomsk State University of Architecture and Building (TSUAB), Russia \\ ${ }^{2}$ Tomsk State Pedagogical University (TSPU), Russia \\ *Email: Ufimtseva80@mail.ru
}

\begin{abstract}
The article evaluates the quality of working life in the Tomsk region and determines the impact of the working life quality indicators of the Tomsk region have on its GRP. Comparative analytical, correlation-regression, and expert evaluation methods were used as the main research methods. Dependencies between the indicators of quality of working life and GRP were established. A conclusion is that, on average, the region GRP for $80 \%$ depends on the quality of working life. Along with this, the possibility of change in pair correlation is not ruled out, because under the influence of events in social, political, and economic spheres the pairs may start correlating differently. To utilize these peculiarities when making managerial decisions all the above mentioned should be tracked and taken into account.
\end{abstract}

Keywords: Quality of working life, Socio-economic development, Correlation.

\section{INTRODUCTION}

The quality of working life determines the degree of successful utilization of labor potential, which, in turn, remains one of the most important indicators of regional socio-economic development. Therefore, the evaluation of the quality of working life has crucial significance, firstly, for the development of effective mechanisms of realization for social-labor policy, secondly, for the development of territory socio-economic improvement program.

A significant contribution to the development of theory and practice in the field of the quality of working life, as well as the evaluation of its quality, was made by scientists such as P.V. Zhuravlev, S.A. Kartashov, B.M. Genkin, A.P. Egorshin, V.I. Yankovskaya, R.A. Katzel, D. Yankelovich, M.A Batasheva, N.A. Gorelov, P.E. Shlender, S. Robinson, G.R. Hackman, G.L. Sattle et al. However, there is no consensus among scientists on the evaluation of the quality of working life.

The working life of an individual is one of the main areas of life which scientists consider as an element and a factor influencing the quality of life of an individual.
Let us have a look at the "working life" term interpretations given in different sources (table 1).

Next, let us focus on the notion of quality, which permeates all sides of the universe and is a key notion in the working life of an individual.

The word "quality" is commonly used, let us take a look at the main interpretations of this term. In the conventional sense, "quality" is the extent to which the inherent distinctive properties of an object match, measured qualitatively or quantitatively, considering a need or expectation that has been established, is usually assumed or obligatory. Quality is associated with the ability to satisfy the consumer, in other words, with the ability to meet certain needs per the purpose [1]. P.S. Mstislavsky states that, in general, human life includes four spheres, namely working, consumer, spiritual and family life [2].

Following the logic of the research, let us focus on the definition of "quality of working life" (table 2), for which there are different interpretations

One can conclude that the quality of working life is a multi-aspect notion. Moreover, the research found out 
Table 1. Interpretations of the term "working life"

\begin{tabular}{|l|l|}
\hline \multicolumn{1}{|c|}{ Author/source } & \multicolumn{1}{|c|}{ Interpretations of the term "working life" } \\
\hline $\begin{array}{l}\text { WorldatWork's Alliance for Work- } \\
\text { Life Progress }\end{array}$ & $\begin{array}{l}\text { a combination of programs, directions, services, and internal relations in a company, } \\
\text { which are specific to stabilization and accumulation of wealth for its employees through } \\
\text { effective management of work, personal life, and family }\end{array}$ \\
\hline $\begin{array}{l}\text { The Work \& Family Connection } \\
\text { company }\end{array}$ & $\begin{array}{l}\text { the practice of providing initiative to create a more flexible, comfortable work } \\
\text { environment, which allows the employees to concentrate on work tasks }\end{array}$ \\
\hline A.A. Zapyrova & life during work time \\
\hline
\end{tabular}

that one group of scientists interprets the quality of working life as an integral indicator, the second as a degree of satisfaction, the third as a complex of working conditions, and the fourth as a combination of factors.

It is fair to conclude the "quality of working life" is a concept that involves the evaluation of a certain number of elements that characterize an individual's working life and its level. The evaluation of the quality of working life is highly important since this assessment can fully serve as the basis for the development of various mechanisms of implementation of social and labor policy.

\section{METHODOLOGY}

To evaluate the quality of working life, statistical data, the results of social polls, and other data are used.

The method of sociological research through questionnaires is the following: a) the main issue when formulating questions for a mass survey is to compose them in a way that allows being understandable to a person who does not have special knowledge; b) the questions in the questionnaire need to be formed in blocks that are centered around a specific issue; c) there is a difference between open and closed questions; d) questions should be formulated neutrally; e) the process of filling out the questionnaire should be as easy as possible; f) the main part should begin with questions that do not cause difficulties for the respondent; g) monotony in the structure of the questionnaire should be avoided; $h$ ) at the end of the questionnaire there are data on gender, age, occupation, place of residence, etc.

Meanwhile, three approaches to evaluation of the quality of working life are conceptual: a subjective approach - based on self-awareness, on the selfperception of workers; absolute approach - based on comparison with uniform established criteria; a relative approach - takes into account specific criteria approved at the local level.

Considered that in the methodological aspect, the evaluation of the quality of working life is bound with 3 approaches: analysis of a varied set of analyzed indicators (parameters); establishment of an integral indicator, which reflects its complexity (a complex of indicators (parameters)); usage of a questionnaire, the questions of which reflect the components of the quality of working life.

It should be noted that the list of analyzed indicators and parameters when evaluating the quality of working life is debatable and remains open. In this regard, we

Table 2. Definition of the notion "quality of working life"

\begin{tabular}{|l|l|}
\hline \multicolumn{1}{|c|}{ Author } & \multicolumn{1}{|c|}{ Definition of the notion "quality of working life" } \\
\hline A.P. Egorshin & $\begin{array}{l}\text { an integral indicator, which comprehensively characterizes the level of spiritual, material, } \\
\text { and medico-ecological state of an individual, as well as the economic development of a } \\
\text { society }\end{array}$ \\
\hline V.I. Yankovskaya [3] & $\begin{array}{l}\text { a certain complex of factors characterizing objective parameters of life for subjects at } \\
\text { work }\end{array}$ \\
\hline $\begin{array}{l}\text { R.A. Katzel, D. Yankelovich } \\
\text { [4] }\end{array}$ & $\begin{array}{l}\text { a combination of the level of contentment of the worker with his labor, his level of interest } \\
\text { and other aspects of his life }\end{array}$ \\
\hline $\begin{array}{l}\text { P.V. Zhuravlev, S.A. } \\
\text { Kartashov }\end{array}$ & $\begin{array}{l}\text { the degree of satisfaction of a worker's personal needs through the activity of an } \\
\text { organization }\end{array}$ \\
\hline S. Robinson [5] & $\begin{array}{l}\text { the organization activity directed at meeting the needs of the employees by creating } \\
\text { mechanisms through which an employee has full access to the making decision process } \\
\text { influences his working life }\end{array}$ \\
\hline
\end{tabular}


will consider the suggested systems of indicators for the evaluation of the quality of working life (table 3 ).

Although most researchers offer different methodological approaches to evaluation of the quality of working life, they all agree that the degree of an individual's satisfaction with working life can be determined using a sociological survey and statistical data taken together.

\section{RESEARCH RESULTS}

Further, as a part of this study, we will evaluate the quality of working life using the example of the Tomsk region. The information base for the research on the quality of the region's working life is the official data of the Federal State Statistics Service of the Tomsk region. Publicly available indicators that reflect the quality of the region's working life were used for the evaluation: employment, labor safety, wages, and qualifications.

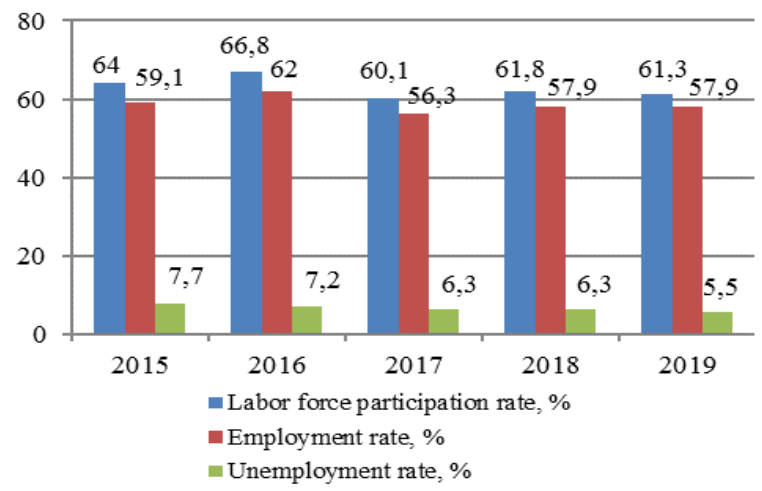

Figure 1 Labor force participation rate, employment and unemployment rates of the population of the Tomsk region.

The labor force participation rate of the population of the Tomsk region in 2018-2019 has been relatively stable. The employment rate has remained the same over the past two years, but its value is higher than the 2017 level, which is a positive change. The unemployment rate of the population of the Tomsk region has a positive tendency to decrease throughout the analyzed period. In general, it should be noted that the decrease in the unemployment rate is caused by several factors: the measures are taken to legalize labor relations, the existing demographic situation. Besides, this is the result of a whole range of measures to modernize the employment bureau considering the requirements of the modern labor market.
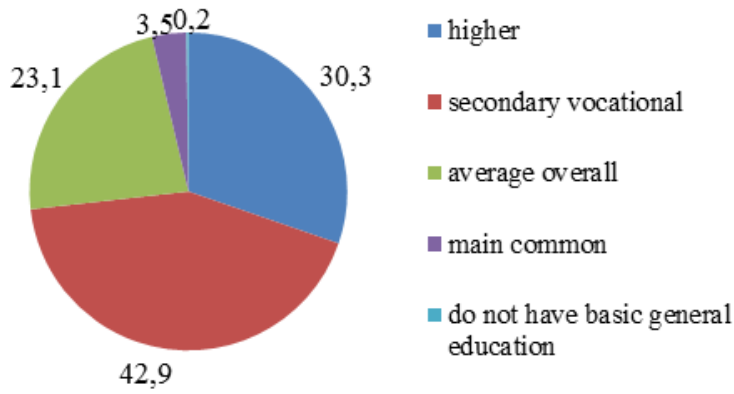

Figure 2 Distribution of the number of employed individuals in the economy of the Tomsk region by education level in 2019, \%.

It is important that the level of education significantly influences the human capital and increases the competitiveness of the Russian economy. In the

Table 3. Approaches to the evaluation of the quality of working life

\begin{tabular}{|l|l|}
\hline \multicolumn{1}{|c|}{ Author } & \multicolumn{1}{|c|}{ A short summary of the approach } \\
\hline L.G. Milyayeva [6] & $\begin{array}{l}\text { the approach contains 7 complex parameters: training organization, proficiency enhancement } \\
\text { and retraining of personnel; maintenance and organization of the personnel's work; assessment } \\
\text { and certification of the personnel; compliance with labor legislature; workplace organization; } \\
\text { staff incentive system; development of organizational culture }\end{array}$ \\
\hline A.P. Egorshin & $\begin{array}{l}\text { the approach suggests analyzing indicators grouped by 7 subsystems of work with personnel: } \\
\text { salary, labor collective, workplace, career opportunities, organization management, social } \\
\text { guarantees, and benefits }\end{array}$ \\
\hline $\begin{array}{l}\text { P.S. Smiths, } \\
\text { S.L. Hoolin [7] }\end{array}$ & $\begin{array}{l}\text { the approach includes the calculation of the JDI (Job Descriptive Index) index, which consists of } \\
\text { 5 components that evaluate the degree of satisfaction with work, pay, management, colleagues, } \\
\text { and career opportunities. Each component of the index contains 9-18 criteria, in general, for } \\
\text { index calculating, answers to 72 questions are considered }\end{array}$ \\
\hline $\begin{array}{l}\text { D.I. Maknab, F.T. Sepik } \\
\text { [8] }\end{array}$ & $\begin{array}{l}\text { the approach evaluates the answers to the questionnaire. The questionnaire has aspects of the } \\
\text { working process: organization of the working process, position requirements, the level of labor } \\
\text { standardization, the degree of job satisfaction, relationships with the colleagues and } \\
\text { management, and the health of employees, etc. }\end{array}$ \\
\hline $\begin{array}{l}\text { S. Staats, } \\
\text { S. Partlo [9] }\end{array}$ & $\begin{array}{l}\text { the approach suggests using a questionnaire, in which the respondent needs to evaluate the work } \\
\text { performed by criteria such as satisfaction with the team, the employer, the customers, the nature } \\
\text { of work, duration and safety of work, remuneration }\end{array}$ \\
\hline
\end{tabular}


region in 2019, the part of people employed in the economy with higher and secondary vocational education is $73.2 \%$, which indicates that qualified specialists work at enterprises and organizations of the region

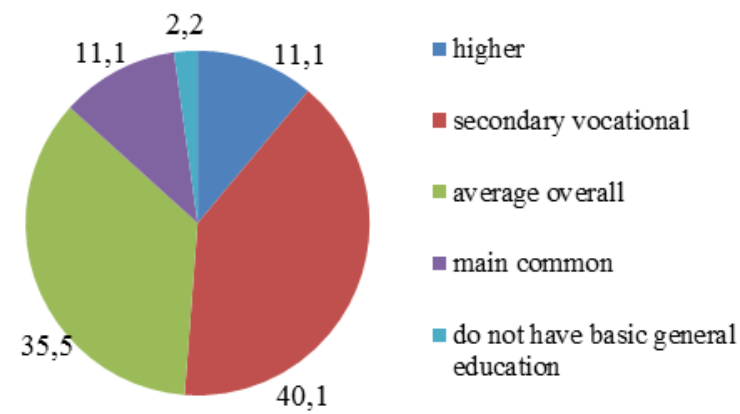

Figure 3 Distribution of the unemployed population of the Tomsk region by education level in $2019, \%$.

Meanwhile, there is a high share of unemployed with higher and secondary vocational education, more than $50 \%$. This may be caused by the lack of job vacancies in the region, the health of the unemployed with this particular level of qualification, etc.

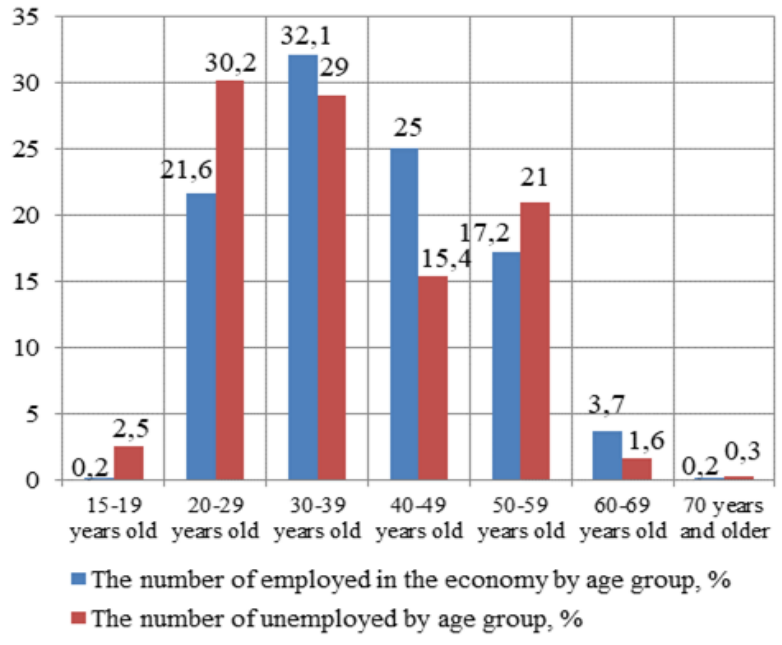

Figure 4 Distribution of the number of employed in the economy and unemployed in the Tomsk region by age groups in 2019.

The largest share of the population employed in the economy in 2019 is in the 30-39 age group. In the subsequent highlighted age groups, the share of the population employed in the economy is gradually decreasing, which may be bound not with a lack of desire to work, but with increased mortality and health conditions. The increase in mortality is indicated by the mortality rates for the main classes of death causes, and the deteriorating health of the population of the Tomsk region is confirmed by the data on the population morbidity for the main disease classes [10].

The share of the unemployed in the 40-49 age group is decreasing compared with the share of the unemployed in the 30-39 age group, however, in the 5059 age group there is a sharp increase observed.

The decrease in the values of indicators in table 4 indicates that sufficient safety measures are being taken and working conditions have been improved.

Workers of agriculture, housing and communal services, and other life-supporting occupations receive wages significantly lower than workers in organizations engaged in the extraction of mineral resources. Workers in the hotel business and public catering have the lowest wages, and the highest wages are in organizations extracting mineral resources (figure 5).

An analysis of the dynamics of the average monthly nominal accrued wages in the Tomsk region indicates a tendency for its increase.

According to Rosstat [11], the median per capita income of the population in 2019 is 22,830 rubles/month. (table 5).

Thus, based on the data in Figure 5 and Table 5 it should be noted that there is significant differentiation between the incomes of those working in the Tomsk region observed.

\section{DISCUSSION OF THE STUDY}

Following the logic of the study, we will perform a correlation-regression analysis, where we will take GRP as a generalizing indicator and trace the closeness of the connection between it and socio-economic indicators reflecting the quality of working life.

Table 4. Industrial injuries and occupational diseases (poisonings) in the Tomsk region

\begin{tabular}{|l|c|c|c|c|c|}
\hline & 2015 & 2016 & 2017 & 2018 \\
\hline $\begin{array}{l}\text { The number of injured in accidents at work with } \\
\text { the following disablement for one working day } \\
\text { or more and with a fatal outcome, people }\end{array}$ & 245 & 251 & 243 & 241 & 218 \\
\hline $\begin{array}{l}\text { The number of victims of industrial accidents } \\
\text { with a fatal outcome, people }\end{array}$ & 8 & 7 & 4 & 12 & 5 \\
\hline $\begin{array}{l}\text { Number of individuals with newly diagnosed } \\
\text { occupational disease (poisoning), people }\end{array}$ & n/a & n/a & 14 & 12 & 12 \\
\hline
\end{tabular}


Table 5. Average, median, and modal level of monetary income of the population of the Tomsk region

\begin{tabular}{|l|c|c|c|c|c|}
\hline & $\begin{array}{c}\text { Average per capita } \\
\text { income of the entire } \\
\text { population (rubles } \\
\text { per month) }\end{array}$ & $\begin{array}{c}\text { Median per capita } \\
\text { income (rubles per } \\
\text { month) }\end{array}$ & $\begin{array}{c}\text { Modal per capita } \\
\text { income (rubles per } \\
\text { month) }\end{array}$ & $\begin{array}{c}\text { Living wage (rubles } \\
\text { per month) }\end{array}$ & $\begin{array}{c}\text { Living wage to } \\
\text { average income ratio, } \\
\%\end{array}$ \\
\hline 2019 & 28391.0 & 22830.0 & 14762.3 & 11465 & 40.4 \\
\hline 2018 & 27296.4 & 21897.5 & 14092.0 & 10907 & 40.0 \\
\hline 2017 & 26697.0 & 21449.3 & 13845.8 & 10747 & 40.3 \\
\hline 2016 & 26165.2 & 21106.7 & 13734.5 & 10706 & 39.4 \\
\hline 2015 & 26827.4 & 21356.2 & 13533.6 & 10578 & \\
\hline
\end{tabular}

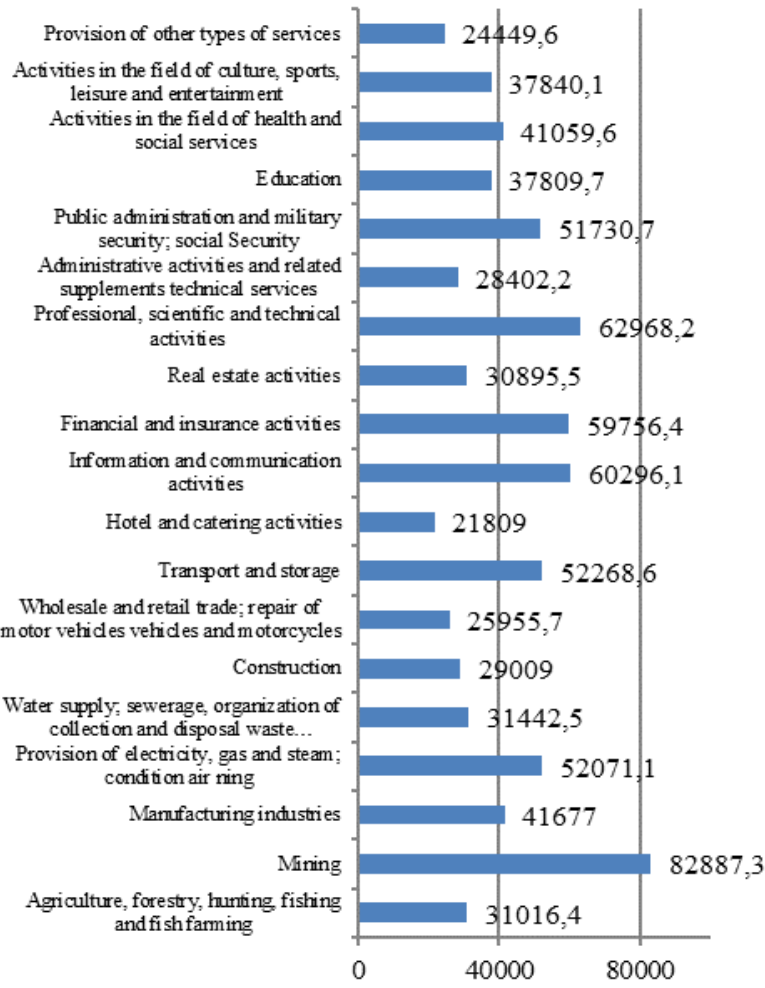

Figure 5 Average monthly nominal accrued wages of employees of organizations in the Tomsk region in 2019 by types of economic activity, rubles

Table 6 demonstrates the results of calculating the correlation coefficient $(\mathrm{R})$ in models of the interconnectedness of indicators reflecting the quality of working life in the Tomsk region and the GRP, indicating the accuracy of the trend model $\left(\mathrm{R}^{2}\right)$, as well as the degree of dependence between the variables based on the results of correlation and regression analysis.

So, both direct and inverse interconnectednesses of various degrees of connectedness have been established: strong, medium and weak. Let us define the direct dependence with a strong connection and model accuracy lower than $60 \%$ (table 7).

Based on the results of the analysis, the employment rate, the average monthly nominal accrued wages significantly affect the GRP of the Tomsk region.

\section{CONCLUSIONS}

Summarizing the main premises of the study, we

Table 6. Matrix of paired correlation coefficients and the fact that there is a relationship between variables

\begin{tabular}{|l|c|c|c|}
\hline \multirow{2}{*}{} & \multicolumn{3}{|c|}{ GRP } \\
\cline { 2 - 4 } & $\mathrm{R}$ & $\mathrm{R} 2$ & correlation \\
\hline Workforce participation level & +0.987904 & 0.3866 & Strong direct \\
\hline Unemployment level & -0.37935 & 0.7981 & Average reverse \\
\hline Employment rate & +0.990968 & 0.7981 & Strong direct \\
\hline $\begin{array}{l}\text { Share of employed in the economy with higher and secondary } \\
\text { education }\end{array}$ & -0.52361 & 0.7734 & Average reverse \\
\hline Average monthly nominal accrued wages & +0.911625 & 0.9693 & Strong direct \\
\hline Employed in harmful and (or) hazardous conditions, people & +0.141239 & 0.5144 & Weak direct \\
\hline
\end{tabular}


Table 7. A strong direct relationship between independent variables with model accuracy of more than $60 \%$

\begin{tabular}{|l|c|c|}
\hline \multicolumn{1}{|c|}{ Dependencies } & Approximation factor $\left(\mathrm{R}^{2}\right)$ & $\begin{array}{c}\text { Share of unaccounted factors in the } \\
\text { presented dependence models }\end{array}$ \\
\hline Employment rate and GRP & $80 \%$ & $20 \%$ \\
\hline $\begin{array}{l}\text { Average monthly nominal accrued wages } \\
\text { and GRP }\end{array}$ & $97 \%$ & $13 \%$ \\
\hline
\end{tabular}

conclude:

1. The conducted correlation-regression analysis showed that, on average, the region's GRP depends for $80 \%$ on the quality of working life.

2. Should be kept in mind, the correlation of pairs is a variable value, this indicates that over time, under the influence of events in the social, political, and economic spheres, pairs may begin to correlate with each other differently - this must be monitored and taken into account to use these features when making managerial decisions. Also, the influence of indicators that currently have medium or weak dependence shouldn't be ignored and should be tracked in time.

3. In our opinion, regardless of the current availability of a significant number of works in the field of evaluation of the quality of working life, the problem being studied cannot be considered solved, because a comprehensive methodological approach to assessing the impact of indicators of quality of working life on regional socio-economic development has not been finally formed.

Therefore, constant monitoring of processes in the field of quality of working life and an assessment of an interrelated indicators system are required to ensure the economic and social development and competitiveness of the territory. The quality of working life undoubtedly improves the quality of human life.

\section{REFERENCES}

[1] E.V. Ufimtseva, M.N. Danilova, Y.V. Podoprigora, A.A. Seliverstov, N.N. Shadeyko, Sushhnostnosoderzhatel'naja harakteristika bjudzhetnyh rashodov municipal'nyh obrazovanij na finansirovanie otraslej gorodskogo hozjajstva [Essential-descriptive characteristic of budget expenses of municipal entities on financing city municipal services], Financial economy 9 (2019) pp. 186-190.

[2] P.S. Mstislavsky, Voprosy teorii i metodologii analiza kachestva zhizni [Theory and methodology issues of quality of life analysis], Standards of living in regions of Russia 2 (2002) pp. 5-24.
[3] V.I. Yankovskaya, Osnovnye sostavlyayushchiye kachestva trudovoy zhizni [Main components of quality of working life]//Standards and quality 2 (2003) 252.

[4] R.A. Katzell, D. Yankelovich, Work, productivity and job saticfaction, Evalution of policy - related research. By R.A. Katzell, D. Yankelovich with M. Fein. N.Y., 1975.

[5] S. Tretyak. Kachestvo trudovoj zhizni: kak ego izmerit' i obespechit' $\mathrm{v}$ sfere uslug? [Quality of working life: how to measure and provide it in the services sector?], S. Tretyak, Business consulting 3 (2005) 39-43.

[6] L.G. Milyayeva Metodicheskie podhody k ocenke kachestva trudovoj zhizni personala organizacii [Methodological approaches to the evaluation of quality of working life of an organization]//Polzun Almanach 1 (2009) 149-155.

[7] P.C. Smith, L.M. Kendall, C.L. Hulin, The measurement of satisfaction in work and retirement, Chicago: Rand McNally, 1969.

[8] D.E. McNabb, F.T. Sepic, Moderating Stress for Quality in the Workplace: Toward a Normative Model, Proceedings of the 21st Annual Meeting of the Western Decision Sciences Institute, Reno, NV, March 25-28, 1992.

[9] Staats S., C. Partlo? «Uplifts, Hassles, and Quality of Life in Workers over 50 Years of Age» in Developments in Quality-of-Life Studies in Marketing, vol. 4, M. Joseph Sirgy, H. Lee Meadow, Don Rahtz, and A.C. Samli (Eds.), pp. 101-106, Blacksburg, Virginia: Academy of Marketing Science, 1992.

[10] Tomskaja oblast' v cifrah, 2020: krat.stat.sb [Tomsk region in numbers, 2020: sh.stat.desc.], Tomskstat-T, 2020, 236 p. Retrieved from: https://istmat.info/files/uploads/55345/tomskaya_o blast_v_cifrah 2020.pdf

[11] Statistics for Russia. Retrieved from: https://rosstat.gov.ru/free doc/new site/population/ bednost/tabl/tab-bed1-2-6.htm 